\title{
The macroeconomics of pension reform: The case of severance pay reform in Italy
}

\author{
Sergio Cesaratto*
}

In the last two decades Italy implemented a number of reforms of the public pay-as-you-go (PAYG) scheme that curtailed future pensions. Governments therefore felt the need to increase the number of workers contributing to fully funded $(F F)$ schemes to offset the expected fall in public pensions. In the private sector an existing saving fund, the severance pay scheme (Trattamento di fine rapporto or TFR) was used to expand the anaemic existing FF pillar. The macroeconomic content of the reform seems fragile since the economy's amount of precautionary saving has not changed. The question is why a bolder reform aiming at creating an additional new old-age saving scheme has not been attempted by the Italian Government. The answer presumably has to do with troubles surrounding the macroeconomics of pension reforms, in particular the difficulties of setting up a $F F$ scheme from scratch or by diverting resources from an existing PAYG program. Not surprisingly, no reform was attempted in the public sector where the TFR works on a PAYG basis. An ancillary argument to defend the reform relies on presumed higher returns from private pension funds (PFs) compared to the old TFR. In this light, the paper examines the nonexiting financial performance of the PFs. The instability of financial markets, even before the current crises, and the fondness of workers for the old TFR are finally used to explain the low popularity of the reform. All in all, the reform seems to be more in the nature of political window-dressing, consisting in a change in management of an existing saving fund, in order to show that something has been done to preserve the future standard of living of retirees.

JEL classifications: EII, G23, H55

Keywords: pension reforms, Sraffian theory, Italy

* University of Siena, Italy. Thanks are due to two anonymous referees who helped me improve the exposition.

Correspondence Address:

Sergio Cesaratto, Department of Political Economy, University of Siena, Piazza San Francesco 7, 53100 Siena, Italy, e-mail: Cesaratto@unisi.it.

Received 23 August 2009, accepted I6 June 2010

(C) INTERVENTION 8 (I), 2OII, 69-89 
In the last two decades Italy attempted a number of reforms of the public pay-as-yougo (PAYG) scheme. The main reform in 1995 reshaped the system as a Notional Defined Contribution (NDC) scheme. The reforms have severely curtailed future pensions, creating the need to find new sources of income for future retirees, so that both centre-right and centreleft governments have considered it urgent to increase the number of workers contributing to fully funded (FF) schemes to compensate for the fall in expected pensions from the first pillar. The solution was found in a change of destination of the 'Trattamento di Fine Rapporto (TFR) (severance pay) - a sort of company-based mandatory saving fund that employers accumulate on behalf of their employees and that the latter withdraw at retirement (or when they leave the firm). Workers contribute about $7 \%$ of their wage to TFR. Though it is not exactly a form of old age savings - it was created to support workers during unemployment spells - the TFR is regarded by workers as a precautionary fund available to them at the beginning of retirement. Between January and June 2007, private sector employees had to decide whether they wished to retain the TFR within the firm or devolve it to a FF scheme. In the latter case, workers could choose between scontractual funds, that is industry-based funds managed by trade unions, or >open f funds, that is standard private pension funds (PFs). The funds diverted to FF schemes have favourable tax treatment and receive an additional contribution from employers, who obtain some tax deductions from the government.

The macroeconomic content of the reform seems fragile: indeed prima facie an existing saving fund (the TFR) has been used to expand the FF scheme, so that it can hardly be maintained that the total amount of precautionary old age saving has increased in spite of the need to prevent the forthcoming fall in future retirees' resources. The reform therefore seems more in the nature of political window-dressing, consisting in a change in management of a pre-existing saving fund, accentuating its old-age motivation. In this regard, the main question we raise in this paper is why the Italian Government has not attempted a more effective reform, aimed at creating an additional new old-age saving plan. The answer must lie in the troubles surrounding the macroeconomics of pension reforms, that is, the difficulty of creating a FF scheme from scratch or by diverting resources from an existing PAYG program. We argue that expansion of FF schemes comes up against two macroeconomic obstacles: (a) workers cannot easily be forced to save more, while it is not possible to divert contributions from PAYG to the FF schemes, since this would create financial problems for the public scheme; (b) even if workers save more, it is analytically wrong to presume that their additional savings will lead to extra investment. Given these difficulties, the only game in town was to change the management of an existing saving scheme. Tellingly, in the public sector, where the TFR is not based on accumulation of savings but on a PAYG principle, the window-dressing reform could not be implemented and indeed no reform was adopted, given the difficulty of transforming a PAYG scheme into a FF one. In order to provide a complete picture of the reform, the paper also examines the argument that the change in management of the TFR funds will lead to better financial results compared to the old TFR, so the change benefits the workers involved after all. The long run financial performance of the PFs has not been impressive compared to that of the old TFR, while the variability of their financial returns has been striking, even before the present financial crises. Moreover, 
the high fiscal costs of the reform should be born in mind, as well as certain artifices used to inflate PF financial performance. In this light, the paper finally assesses the popularity of the reform among private sector workers. Although the number of PF members has risen, most Italian workers are still not affiliated with a PF. Lack of information and employer pressure to leave the TFR with the firm are possible reasons; lack of trust in the promise of higher and safe financial returns from the PFs is another.

Section I briefly recalls the impact of the first wave of PAYG reforms on expected public pensions that prompted the alleged need for a second wave of reforms, aimed at strengthening the FF second pillar. Section 2 deals with the smacroeconomic difficulties surrounding this further reform step. Section 3 illustrates the institutional details of the TFR reform and Section 4 its frail macroeconomic implications. Section 5 assesses the financial performance of PFs compared to the old TFR. In this light, Section 6 appraises the low popularity of the reform among workers. Section 7 offers our assessment of the TFR reform and sketches an alternative. The conclusions sum up the main points.

\section{Pension reforms in Italy}

The Italian pension system is mainly based on a public PAYG scheme, with a subsidiary FF component. Up to the early I990s the PAYG scheme was organised on a defined benefit (DB) principle characterised by a relatively generous replacement rate (the ratio of the first pension cheque to the last wage) and by wage indexation of pensions. In order to reduce pension spending, the `Amato reform ‘ of 1992 and the `Dini reform ' of 1995 (after the names of the then prime ministers) reformed the PAYG scheme as a NDC scheme. ${ }^{I}$ In this scheme, pension benefits closely depend on past contributions, as in a virtual bank, and this implies lower replacement rates compared to the DB scheme, particularly for workers with dynamic wage careers. In addition, pension benefits would progressively fall with increases in life expectancy at retirement (the accumulated contributions are returned by the virtual bank in smaller amounts over the longer survival period). Finally, the rate of return that the virtual bank pays on contributions is strictly dependent on the financial capability of the system. This depends on the growth rate of the aggregate wage bill - on which the growth rate of the contribution flow depends - so that whenever this growth slows down, or becomes negative (as in 2009), it would have a negative effect on pension benefits. As a result, replacement rates would fall from the current $70 \%$ to $50 / 60 \%$, and much less for workers with fragmented job histories. On one hand, the reform has been successful in stabilising long run public pension spending on the GDP in Italy; on the other hand, politicians and trade unions were relying on the second FF pillar to compensate for the fall in expected pensions from the first PAYG pillar. This was not an easy task. To appreciate the second wave of Italian pension reforms, this time devoted to reinforcing the FF component, it is necessary to explain the difficulties surrounding the creation of a FF scheme.

I On NDC schemes, see the World Bank (200I), Cesaratto (2005: ch. I); on the Italian NDC reform see Franco and Sartor (2006), Gronchi and Nisticò (2006), Cesaratto (2005: ch. 2). 


\section{The economics of FF pension reforms}

As known, in a pure pay-as-you-go program, current contributions are used to pay current pension benefits, and this is generally true from the very inception of the system. In contrast, in the setting-up phase of a genuine FF scheme, contributions should, in principle, be used to accumulate real reserves in the form of capital assets, such as securities representing real capital assets. This original accumulation must consist of net capital accumulation, which is a net addition to the capital stock (Cesaratto 2005: 95-98). This is easy to perceive if we recall the Keynesian concept of >old age provision ‘ as one of the main motivations for saving (Keynes 1936: I07-I08): a successful fully funded reform increases the aggregate old age provision if there is a net addition to the aggregate capital stock. According to the dominant neoclassical theory, the advantage of a FF reform thus lies both in increasing the individual old age provision and in its capacity to increase the per capita capital endowment and per capita income.

A mature FF scheme resembles a PAYG scheme in so far as the younger generation of workers buy the capital assets from the older generations, thus financing their old age. It is indeed true that in any mature pension scheme it is the active generation that has to sustain the older age group. This support takes place through a market exchange in a FF scheme and through a moral and political pact amongst generations in a PAYG scheme.

Private PFs and the State typically act as buffers in FF and PAYG systems, respectively. In the first case PFs accumulate and then sell assets on behalf of workers; in the second case public social security agencies simply transfer the pension contributions from workers to retirees, although the State has a fundamental role in making participation in the system mandatory and retains the power to change the rules of the game. ${ }^{2}$

Very often, preference between the two systems is based on comparison of the rates of return on contributions. Yet, it has been pointed out that this is methodologically wrong since it assumes that a FF scheme can be created at will, by mere policy design, but this is not true, as we shall now show. ${ }^{3}$

There are, indeed, at least two obstacles to a FF reform: (A) the marginal propensity to save cannot be raised at will; and, even if it were to be successfully increased, (B) the

2 The similarity of the two systems should not be overstated. According to various scholars (e.g. Barr/Diamond 2006: 33) the resemblance of the two schemes suggests that they would both meet the same difficulties if the economic dependency ratio - the ratio of retirees to workers - were to worsen as an effect of demographic trends. This is correct as far as it goes, but it fails to take full account of the neoclassical claim that the FF scheme is more robust than PAYG in facing this kind of shock. Cesaratto (2007) appraised this assertion, indicating its flaws and concluding that it is not a solid one.

3 Cesaratto (2005: 9I) criticised economists who "just compare the rate of return on contributions in the two systems - the sbiological rater of PAYG, and the rate of return on investment of [a fully funded] scheme - without discussing the transition difficulties and macroeconomic implications of adopting one of the two competing programmes" (see also Cesaratto 2006a: 34). This methodological criticism has subsequently been adopted, almost literally, by Barr/Diamond (2006: 22): »It is mistaken to focus on a pension system in steady state, while ignoring or underplaying the necessary transition steps to get from one steady state to another". 
neoclassical causal relationship whereby more saving leads to more investment has analytically been shown to be controversial.

(A) It is politically difficult to impose a mandatory diversion of part of disposable income to PFs. Moreover, this measure might be followed by a corresponding fall in discretionary (voluntary) saving, so that the total amount of precautionary saving does not rise. This substitution effect is less likely (i) if discretionary saving behaviour is mainly explained by a bequest intention and not by the old age motive, ${ }^{4}$ and (ii) if workers are wealthy enough to save but myopic with regard to their old age provision (see Barr 2006: 13, Barr/Diamond 2006: 30, Cesaratto 2005: II7-I22 and 2006a: 37-39 for the references to previous literature).5 The political difficulties related to imposing further compulsory old-age saving are more probable when a PAYG scheme is already in place. The reform would indeed require workers to continue to pay PAYG contributions without expecting a PAYG pension, as well as contributing to PFs to build their new FF pension.

Various proposals have been advanced to avoid painful shifts from PAYG to FF schemes, in the form of transition plans to avoid the double burden on workers of new mandatory oldage savings on top of the existing PAYG contributions. Naively, these plans (e.g. Holzmann I998) have relied on the full or partial diversion of PAYG contributions to a FF scheme, with the government intervening to make up for the payment of current pensions (Cesaratto 2005: ch. 4). This move would indeed entail either:

(i) an increase in taxation, which, if levied on workers themselves, would mean that total mandatory social contributions were in practice increasing. This measure would clearly be equivalent to a double contribution from current workers - one to support the current PAYG retirees and the second to build their own FF pensions ${ }^{6}-$ a measure that would be politically unpopular (and that might be matched by a fall in discretionary savings); or

(ii) an increase in public debt. In this case one could, in a first approximation, think that the PAYG contributions diverted to the PFs would be used to buy the public bonds issued by the government to make up for the social security deficit. Some commentators would jump to the conclusion that a funded system has, after all, been created, but closer scrutiny easily reveals that this is not a genuinely fully funded scheme, in so far as the economy has not seen a net accumulation of real reserves (i.e. real capital assets). ${ }^{7}$

4 Note, however, that the bequest and old-age motives cannot be clearly distinguished, since one can accumulate assets for both reasons and the actual final use may be decided by circumstances later in life.

5 In Chile, workers were too poor or had too irregular jobs to contribute to a FF scheme. This is one main reason why, as now generally recognised, the famous Chilean PF reform failed (e.g. Barr/ Diamond 2006: 23I-232).

6 A double contribution would of course be necessary as long as there are PAYG retirees.

7 The great Italian mathematician and actuary Bruno de Finetti was perhaps too optimistic in 1956 when he wrote: "[A]lmost all authors seem to agree that it would simply be window-dressing if the capitalisation consisted in investments in public debt." (de Finetti 1956: 279, my translation). 
As a leading neoclassical economist and 'pension expert ‘ put it:

"In this putative shell game, workers, in the new regime, make contributions to their pension funds, rather than to the government, and the pension fund turns around and gives the contributions right back to the government as loans «. ${ }^{8}$ (Kotlikoff I999: I6-I7)

These arguments have by now been endorsed by the literature, though not necessarily by all spension experts،. There is, moreover, an important divergence between orthodox and non orthodox scholars. Mainstream students believe that were it not for the abovementioned difficulties, a successful rise in old age saving would lead to higher per capita capital and income. This should be firmly denied by heterodox scholars. In this respect, the role of the saving-investment causal nexus in pension reforms has been somewhat misrepresented.

(B) Suppose that a FF reform induces a rise in the marginal propensity to save, in spite of the above difficulties. In this regard Barr and Diamond (2006: 33) concede that the connection between saving and investment is more complex than neoclassical theory would like it to be. More specifically, Barr acknowledges that:

»it may not be right to argue that additional savings are always translated into productive investment via adjustments in the interest rate - the Keynesian argument that higher saving together with sluggish investment may lead to stagnation rather than growth may not be wholly dead«. (Barr 2006: 13)

However, there is no in-depth analysis of this point in Barr and Diamond (2006). As known, according to neoclassical economics, given the labour stock, an increase in the saving supply entails a higher capital-labour ratio. More specifically, a larger saving supply leads to a lower interest rate and, given a decreasing demand curve for capital, to a higher per-worker capital endowment. The idea that the demand for capital - of which the investment function is a scale copy - is a decreasing function of the interest rate depends on the decreasing shape of the factors' marginal product curve. The capital theory controversy, initiated by Piero Sraffa (1960), suggests that neoclassical capital theory is vitiated by logical faults. ${ }^{9}$ The following years saw pugnacious debate between a group of mainly Italian economists associated with Cambridge (UK) and top American economists located at the MIT in Cambridge (US)

8 Kotlikoff continues: „So the cash flow from the workers to the government remains the same. In the old system, workers receive implicit I.O.U.s to future government pension benefits in exchange for their contributions, whereas under the new system they receive, via their pension funds, explicit I.O.U.s (government bonds) that promise to pay interest and principal. If the implicit and explicit I.O.U.s have the same present value, then the ‘reform has not reduced the present value of the government's future expenditure - it has simply relabelled them." The famous and initially allegedly successful Chilean transition to a FF scheme was financed by crafting a budget surplus first obtained by cutting social spending (cf. Cesaratto 2005: ch. 4).

9 Unfortunately, the belief that Joan Robinson (1953/4) opened the capital controversy in the early fifties is widespread. Ms Robinson actually took some hints about the problems in capital theory from Sraffa, but her paper lacked the rigour necessary to sustain the controversy. 
led by the don of neoclassical economics, Paul Samuelson. Following Harcourt's (1972) contribution, the debate became known as the controversy between the two Cambridges.

As far as this paper is concerned, the main result of the capital controversy is that it is not possible to rigorously draw a demand curve for investment as a decreasing function of the interest rate (Garegnani 1983). We therefore conclude that even if a pension reform is successful in raising the marginal propensity to save, there is no reason to believe that this would lead to higher investment and to higher per worker capital endowment and productivity. Quite the opposite: Keynes' ‘saving paradox` would apply, whereby a higher marginal propensity to save entails a lower income level - just enough to generate savings equal to the given investment level decided by entrepreneurs (Cesaratto 2006a and 2006b).

While this last objection may provide further ammunition for critics of FF reforms, the first set of difficulties is more relevant in practice, since it is accepted even by neoclassical economists and is perceived by policy makers, for instance by Italian politicians wishing to reinforce the FF component after the cutback of the first pillar.

\section{The institutional features of TFR reform}

The previous section illustrated the difficulties of creating a FF scheme from scratch or by diverting resources from an existing PAYG scheme. With reference to the first set of objections, in Italy it was particularly difficult to introduce a further mandatory pension contribution to the PFs because of the high level of PAYG payroll taxes $-33 \%$ of the gross wage - to which the contribution to the severance pay fund or TFR, $7 \%$, had to be added. ${ }^{\text {Io }}$ An additional mandatory contribution to PFs would have been politically unpalatable, and if implemented it would certainly have determined a fall in voluntary savings, leaving workers' precautionary saving unchanged. Transition plans proposed in Italy by Castellino and Fornero (1997) and Ceprini and Modigliani (1998) never entered the political debate, with good reason, considering their inconsistency.

Since the early I990s, a stratagem to overcome these difficulties has been found for the private sector in the shift of the TFR to the PFs. Let us illustrate some details of the reform first, commenting on its effects in the next sections. The TFR is a mandatory severancepay scheme (see Cesari et al. 2007) in which 7.4I\% of gross wages is accumulated by private employees in a saving fund that may be interpreted as an >occupational fund ‘ at corporate level. The rule of thumb used by workers is that the TFR received when they leave the firm is roughly equal to one month's salary per year worked. Trade unionists and workers often call the TFR a deferred wager. Unlike the US $40 I(k)$ funds, TFR funds are used directly by the firm, and should the firm go bankrupt a co-insurance fund managed by the main State pension agency (the National Social Security Institute - INPS) intervenes, so an Italian Enron

Io The high contribution rate to the PAYG scheme is not mainly due to particularly generous pensions, but to the low employment rate (number of employed divided by the population of working age) in Italy, $57.9 \%$ in 2009 against $65.9 \%$ in the EU-I5 (source: Bank of Italy). 
case can be ruled out. Indeed, 0.5 points out of 7.4I are devoted to this purpose. A yearly rate of return equivalent to $\mathrm{I} .5 \%$ plus $75 \%$ of the inflation rate is yielded on accumulated TFR funds. This implies that the real rate of return will be positive - net of II\% tax - up to an inflation rate of $4 \% .^{.}$

If we examine a fully operating TFR scheme over a period - at company or aggregate level - we may distinguish between (i) TFR flows: TFR inflow out of gross salaries, and TFR outflow in the form of severance pay to those who leave the firm; and (ii) the TFR stock, that is the debt towards workers that firms accumulate as a result of the difference, or net flow, between TFR inflow and outflow (typically the net flow is positive during the inception period when outflow is nil). For firms this debt is equivalent to a loan obtained, say, through the emission of bonds. The TFR is therefore often said to be a cheap way for firms to borrow. Official estimations posit the yearly flow of TFR at about 19 billion Euros ${ }^{12}$, while the stock is estimated at about 2Io billion (Boeri 2008). The reform diverts TFR inflow to the PFs. In this event, firms have to find alternative and more costly ways to finance TFR outflow, if they want to maintain the amount of capital stock - own and borrowed - intact.

Two reform bills, the most important one in 1993 and another in 200I, have encouraged workers in the private sector to devolve their incoming TFR flow to PFs. The legislation prescribed two main kinds of PFs: the first, commonly known as ıcontractual funds`, are industry-based and instituted within national labour contracts or by professional associations and managed by trade unions. The second `open type coincides with standard PFs. The contractual funds entrust the practical management of the TFR funds to external financial companies. Given the limited success of these reform bills, in 2004 the centre-right government emanated a third bill that proposed further tax advantages for both workers and firms and, more importantly, a default clause ('silenzio-assenso ‘) whereby a worker's TFR flow would automatically be diverted to a contractual PF (if existent) unless the worker explicitly opposed this and opted to maintain the TFR within the firm. In 2006 the centreleft government, with the Trade Unions' consent, rescheduled the reform, implementing it one year earlier, from Ist January 2007. Workers were given six months to decide which PF - scontractual or sopen - they wanted to direct their TFR flow to, or to expressly oppose this designation. If they explicitly opted for a contractual fund and added about I.2 percent of their gross salary to the TFR flow, employees would also benefit from a similar addition from the employer. If, instead, they adhered to PFs only by default, they lost out on the employer's contribution. In this case the TFR was devolved to a contractual fund or, if there

II With an inflation rate of $4 \%$ the gross rate of return would be $\mathrm{I} .5 \%+3 \%=4.5 \%$. The after tax rate would be approx. $4 \%$. The severance pay may be partially withdrawn by workers before their leaving the firm to finance e.g. health expenditure or the purchase of a house.

I2 Of which I billion was already devoted to PFs before the 2007 reform, cf. Messori (2007: fn 40). Other estimations posit the value of the TFR flow in the industrial sector at I6.2 billion Euros, including the financial sector at 18 billion (Chiorazzo/Milani 2007). 
was none in their specific industry, to a special PF administered by INPS. ${ }^{\mathrm{I} 3}$ The reform bills decree that once they retire, workers have to transform half of their accumulated savings into an annuity.

To summarize, a worker who allocated all his/her TFR to a closed fund conferred $7.4 \mathrm{I} \%$ points of the gross wage, minus $0.5 \%$ which was transferred to INPS for the TFR insurance, plus an additional I. $2 \%$ points of his/her gross wage, plus I.2\% points of the gross wage added by the employer, for a total of $9 \cdot 30 \%$. Since the precise size of the employer's contribution is decided by industry labour contracts, this contribution enters the wage bargaining process (e.g. the metal workers contract signed in autumn 2009). It is therefore legitimate to believe that the employer's contribution is deducted from otherwise expected increases in workers' gross wages, i.e. it is paid by the workers themselves.

Whatever their preferred PF - contractual or open - workers had the option of selecting the degree of risk of their financial investment.

A particular collateral feature of the recent implementation of this reform, though not our direct concern, regards the destination of the TFR flow expressly left within the firm (that is, flow not opted out explicitly or by default). Firms with more than 50 employees have to switch these funds to a special account held by INPS on behalf of the Treasury, which should be employed, it was argued, to finance infrastructure ( 6 billion Euros were expected in 2008). Nothing would change for individual workers in terms of TFR rights, but firms would lose the TFR inflow. Ultimately, the only non-opted out TFR flow that would remain in firms would be in firms with less than 50 employees. Firms were promised financial compensation in the form of tax relief for the higher costs of finance in all cases in which they lost the TFR flow.

\section{The macroeconomic results of the TFR reform}

As we have seen, the TFR is a mandatory saving plan at firm level in the private sector, so what the TFR reform actually does is transform one saving scheme into another. This is not surprising, in view of the difficulties of creating a new FF scheme illustrated in section 3. In Kotlikoff's parlance, we are facing another shell gamer. In the first approximation, we may even think that PFs that collect the TFR flow will use it to finance the firms that have lost the TFR flow. Of course things are actually more complicated, in the sense that the PFs will not necessarily directly invest in firms that have lost the TFR flow, but will buy a plethora of national and foreign assets. However, there is more than a grain of sense in arguing that this reform simply led to a reshuffling of financial flows, with no direct impact

I3 Workers who opt for pension funds only by default are treated as particularly risk-adverse individuals and, according to the regulations, their funds must be managed in a particularly prudential way, guaranteeing full preservation of the principal and having the TFR rate of return as benchmark. 
on investment (e.g. some subjects will stock fewer government bonds, selling them to PFs, and hold more private financial assets). ${ }^{\mathrm{I}}$

Not surprisingly the reform did not take place in the public sector. The severance pay scheme, which can be likened to a savings scheme at firm level in the private sector, works roughly on a PAYG principle in the public sector: basically, since the inception of the scheme current contributions have been used by the State to pay the TFR outflow to those who retire or leave a public job. If the State allowed public employees to divert their TFR flow to PFs, payment of accumulated TFR would have to be financed in some other way. To recall the most straightforward case (see Section 2), if it were financed by issuing public debt, then the greater private savings of the public employees (corresponding to TFR flow accruing to PFs) would be precisely compensated by smaller public savings; prima facie PFs would use the accruing TFR flow to buy treasury bonds issued by the government. Another shell gamer. The difficulties of managing the transition from a PAYG-based severance pay scheme to a FF scheme explain why this has not yet been implemented in the public sector, leaving aside some marginal cases (the main one being the contractual fund in the public schools sector) despite the stated political will to do so. ${ }^{15}$ As a result, only $4 \%$ (I39,000 workers) of the public sector employees were affiliated with a PF in 2009.

Given the poor macroeconomic content of the reform, an argument in support is that diversion of TFR flow to intermediation of the financial sector will help improve the rather underdeveloped Italian capital market, by inducing greater participation by small and medium enterprises (SMEs) in particular. ${ }^{16}$ The justification would be that the presence of institutional investors (such as PFs) capable of assessing the investment opportunities offered by promising SMEs would encourage investment in their assets, thus reducing the cost of access to the stock market for these firms. All this would presumably spur investment by innovative SMEs. However, the idea that inefficient firms that lose the cheaper TFR finance would be purged in favour of more innovative and profitable firms that can afford a higher interest rate is at odds with the government compensation given to all firms that slose the TFR. More importantly, this is frankly too tenuous an argument for a pension reform to rely on.

For completeness, we must remark that the only macroeconomic effect of the TFR reform we are left with would concern the abovementioned acquisition by the Treasury of the non-opted out TFR funds in the larger firms and their presumed use to finance public investment. From a macroeconomic viewpoint this would sound like a Keynesian

I4 The TFR reform has also been criticised, arguing that there is a risk that savings are taken abroad instead of being invested at home. This is also a non-Keynesian argument that I have appraised elsewhere (Cesaratto 2005: 219-220).

I5 In recent years the public budget has allocated around roo million Euros per year to financing TFR reform in the public sector. The cost of financing the reform for all public employees would be significantly larger.

I6 Notably, this argument implicitly recognises that at first sight the reform just leads to a reshuffling of the financial flows. 
measure, although this manner of financing public investment might be more expensive than standard debt financing, since the government not only has to pay a rate of return on the TFR funds borrowed from workers, but also has to compensate firms for the ^loss of TFR inflow. Moreover, we do not know whether the public investment concerned would have been made anyway. This investment may really be additional, since while the accruing TFR is a current source of additional finance, future pension payments do not officially appear as debt - as all pension debt is ıimplicit` - so they do not count in terms of observing the European treaties. In short, the government has received fresh money without raising taxation or the public debt. The expected 6 billion Euros of TFR flow actually accrued to the Treasury. However, this has nothing to do with pensions.

With regard to pensions, the remaining most influential argument in defence of the TFR reform is the promise of a higher financial return from PFs than from the old TFR. Let us examine this claim.

\section{Financial returns on workers' savings before and after the reform}

According to the official projections (RGS 2008: tables 6.Ia/b), assuming a yearly real rate of return of $2 \%$, diversion of $6.91 \%$ points of the gross wage, corresponding to moving the TFR to PFs, would imply that in 2040 the net replacement rate (the ratio of the first pension cheque from both public and private pillars to the last wage, both net of taxes) for an average employee retiring at 63 with 35 years of contributions paid would be $79.5 \%$ instead of $63.9 \%$, with only the public component. By comparison, in 2007 the public pillar provided a net substitution rate of $8 \mathrm{I} .6 \%$. The comparison is indeed not fair, since employees retiring in 2007 also got their accumulated TFR, which could in principle be transformed into an annuity, so that the true replacement rate was well above $8 \mathrm{r} .6 \%$.

Advocates of the reform can nonetheless argue that the TFR will more satisfactorily supplement the public component under PF management than before the reform. There are two problems, however: (i) Is the hypothesis on the rate of return from PFs ( $2 \%$ real) reliable? (ii) Should we not also consider the fiscal costs of the reform, most of which are born by employees.

Regarding the first problem, financial returns from the TFR (I.5\% plus $75 \%$ of the inflation rate) are usually taken as the benchmark to assess the performance of PFs. This is suggested by the legislator who stated, as noted before, that for those workers who tacitly accepted that their TFR be diverted to PFs - therefore without explicitly selecting a more or less risky specific line of financial investment - the PFs must guarantee a safe rate of return, comparable in real terms to that of the TFR, by investing in a prudent way. Table I (on p. 8I) shows official data on the actual performance of the contractual and open PFs over the period 1999-20I0. The geometric averages of the net nominal rates of returns over the period show that the TFR rate $(2.9 \%)$ is not far below that of the contractual PFs (3.I\%) and beats that of the open PFs (2.I\%). Had a worker invested €Ioo per year from I999, s/he would have received $€ \mathrm{I} 294$ from the old TFR in September 2010 and $€ \mathrm{I} 290$ and $€ \mathrm{II} 49$ from 
the contractual and open PFs, respectively. Although drawn from too short an experience, these results suggest that it is not certain that the PFs would easily beat returns from the TFR, as argued by supporters of TFR reform, and at the same time guarantee safe forms of investment. Notably, these nominal rates are not sufficient to generate the real rate of $2 \%$ used by the official authorities to calculate the post reform future replacement rates (as a reminder, the average inflation rate in Italy over the period I999-2008 was 2.5\%).

This short experience can also be taken as representative of the instability of the financial markets in recent decades. The variability of the financial returns of PFs, measured by the standard deviation, is much higher than that of the TFR: tenfold in the case of contractual funds, twentyfold in the case of open funds. The two waves of financial turbulence in 200I2 and 2008 are clearly discernible in the table with very negative rates of return. In both cases the open funds lost more than the contractual funds. ${ }^{17}$ In the aftermath of the current financial crises, the surveillance authority declared, in a parliamentary hearing, that only a few PFs had 'toxic ‘ assets in their portfolios, and these were for negligible amounts (COVIP 2009b: I). Indeed, in 2008, the fall of the rate of return of the Italian PFs was lower than the OECD average (-2I.4\%), given the prudential risk profile of most of the affiliated (COVIP 20IOa: I8). This is attributed to their relatively high average age. The authority of course applauded the positive performance of the PFs in 2009 (ibid: 3), instead of suspecting the robustness of the financial market upturn, supported as it was by the huge amount of liquidity made available by the central banks, while the real economy was still far from a firm recovery. The recovery was not sufficient, however, to beat the TFR: over 2008-09 the contractual funds realised a rate of return of $\mathrm{I} .7 \%$, and the open funds a negative one, against $4.7 \%$ of the TFR (ibid: 19). Those who retired in 2008 suffered a fall in revenues of about IO-20\% compared to those who retired the year before (ibid: 20 ).

Leaving aside the current vicissitudes, the various institutions with vested interests in the TFR reform contend that the long period advantage of the reform lies (a) in the fiscal benefits and (b) in employers' contributions to workers who deliberately devolved their TFR to contractual PFs. Let us briefly examine these claims.

(a) Let us assume, for the sake of the argument, that a higher interest rate should be expected by workers who embrace the reform since their TFR savings are now lent at a market interest rate. However, as long as firms are fully compensated for the higher interest costs of external finance (compared to the very low cost of TFR), ${ }^{\mathrm{I}}{ }^{8}$ the only change is for the public

I7 Evocatively, in early winter 2008 the government discussed a bill aimed at offsetting the losses of those retiring between September 2008 and August 2009 (compensation limited to the TFR devoted to $\mathrm{PFs}$ ). Another proposed intervention regarded the opportunity of postponing transformation of the capital accumulated into an annuity until the stock market had recovered; and a third was to limit information to PF members regarding the performance of their funds to every three months, instead of every month, in order to avoid irrational withdrawal decisions (Il Sole 24 Ore, 23/II/2008). None of these measures was taken, but such was the panic among supporters of the TFR reform.

I8 Unfortunately, official data is not available. In 200 a government commission estimated that the unsuccessful , take-off of the second pillar over the period 1996-2000 implied savings of about 2 billion Euros (Commissione ministeriale per la valutazione degli effetti della legge n. 335/1995 e successivi 


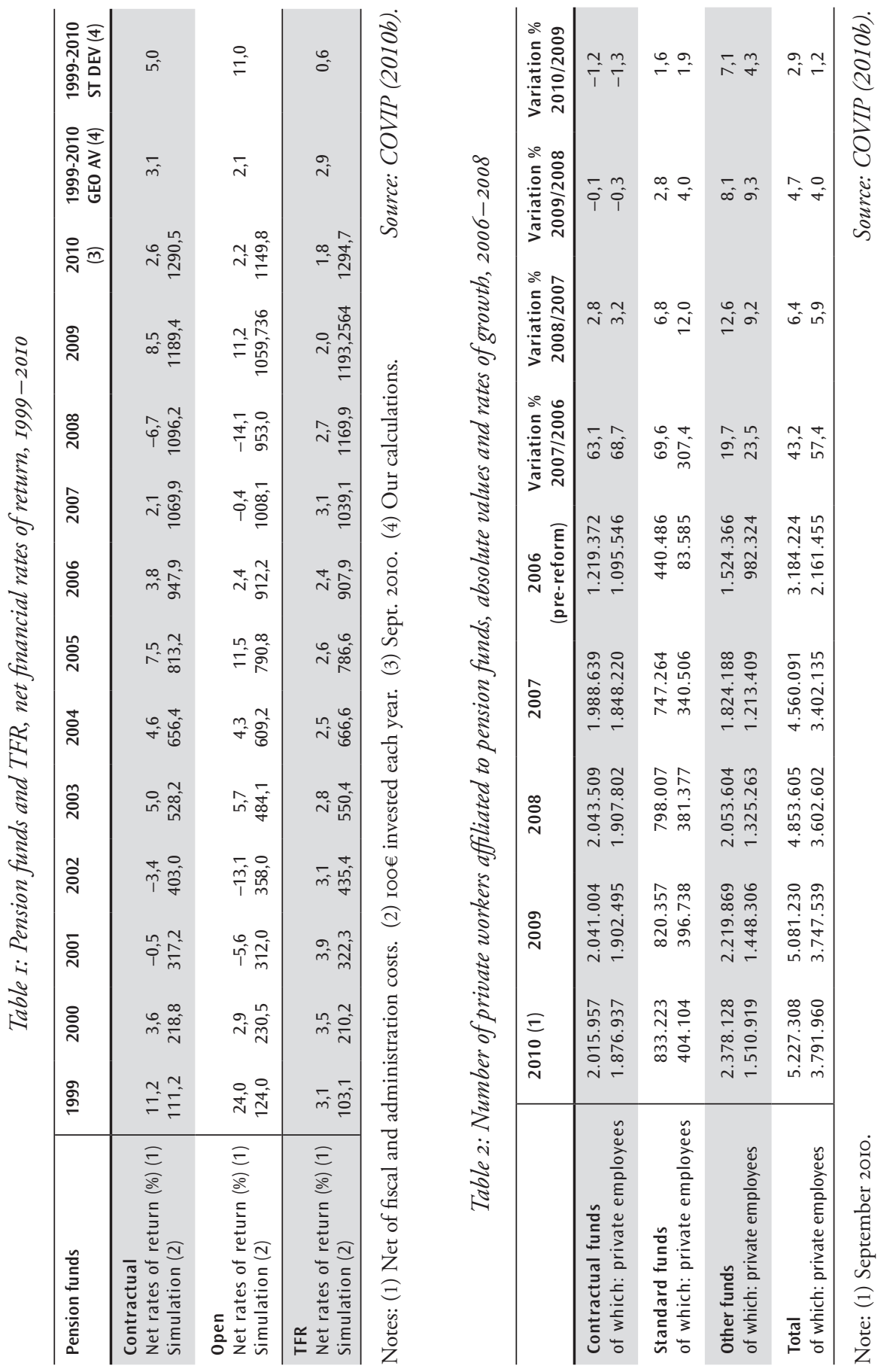


budget, which also bears the costs of the tax concessions granted to PF savings, which mainly benefit richer workers (including professionals etc.). ${ }^{19}$ Therefore, even admitting that higher interest revenues from the TFR managed by PFs actually accrue to workers, this advantage is fully paid by the State and it is questionable whether this is the best way to spend tax-payers' money. Moreover, if we suppose that most of this money is paid by workers themselves through higher taxation (e.g. via fiscal drag) and by cuts in social spending (that is by cuts in their social wage), then the reform is at best a zero sum game for employees. ${ }^{20}$ Finally, the higher administration costs of the TFR managed by PFs compared to the negligible management costs of the old TFR should be considered. The financial sector seems likely to be the only net gainer.

(b) If the tax advantages are largely financed by employees themselves, in a similar vein the contribution from employers is clearly part of the contractual real wage. It is therefore quite misleading to mask what is actually workers' money as financial returns, as the trade union-sponsored contractual PFs unfortunately do. ${ }^{21}$

provvedimenti). The State budget for 2007 allocated 414 million Euros for 2008 and 460 for the following years as tax relief for firms. These are estimated to be very generous (Chiorazzo/Milani 2007). In addition to this, the former centre-left government introduced substantial reductions of the tax wedge in favour of firms, of the order of over 4 billion Euros, claiming that this should also have appeased firms for the cost of the lost TFR, which was of the order of hundreds of millions of Euros. I9 Financial returns from both the TFR left to firms and the TFR invested in PFs are taxed at II\% (compared to I2.5\% generally applied to other financial assets). While the TFR contributions, irrespectively of whether they are left with the firm or diverted to PFs, are not part of taxable income, the accumulated stock at the end of the working life is treated differently: in the former case the stock is taxed at the income tax rate, which for an ordinary worker is at least $23 \%$ and in the latter case the stock is taxed at $15 \%$ or even less, depending on the number of years of contributions (after I5 years the tax rate is reduced by $0.3 \%$ for every additional year, so after 35 years of contributions the final rate is $9 \%$ ). Note that tax savings from deductibility depend on the marginal rate, which is progressive, so those savings are highly regressive, as often denounced in the literature critical of FF schemes. Moreover, yearly contributions to PFs are deductible from gross taxable income up to $€$ 5164, to the advantage of higher earners (an ordinary employee would on average contribute $€ \mathrm{I} 400-1500$ per year). Self-employed workers do not accumulate TFR, but they benefit from the tax relief granted to those affiliated with pension funds, which is odd in view of the high tax avoidance of this class of workers in Italy. It is not hazardous to say that most tax relief is accrued to richer workers. In this regard, data from the UK is impressive. According to Agulnik and Le Grand (1998) tax relief is highly regressive, with half the benefit received by the top IO\% of taxpayers and a quarter by the top 2.5\%. Arber and Ginn (2004) estimate an expenditure on tax relief and rebates of over 2.5\% of GDP and rising. Presumably, richer workers would have saved also without these gifts.

20 Self-employed labour is notorious for tax-dodging in Italy, and in this regard supporters of indulgent centre-right governments. Its share of the Italian labour force is much larger than in the EU-IS (25.8\% against 15.4\%, respectively, in 2008, source: Bank of Italy). So the tax burden on wage earners is much heavier in relation to its share of the labour force and of GDP.

2I An example of the unreliable information workers receive even from the contractual funds managed by the Trade Unions is that of Cometa, the main contractual fund for metalworkers. By including the employer's contribution in the financial return of PFs, Cometa was able to show a 20.3\% 
To sum up: (i) the reform merely changes the financial flows in the economy, with no clear macroeconomic effect (certainly not a higher savings rate which, according to conventional theory, is a prerequisite for the creation of a new FF scheme); (ii) the financial returns from PFs over the past decade have not been higher than those from the TFR, a dismal result that must also be judged in terms of the fiscal costs of the reform - of which official estimations would be crucial - mostly paid by wage earners.

Thus the TFR reform consisted in a change of management of an existing, well functioning and widely popular saving fund, a change that brought dubious benefits. It can therefore be concluded that the reform was an attempt to deceive workers that their future pension replacement rates would be preserved after the cuts expected by the PAYG reforms of the I990s: an exercise in political window-dressing. In this light, let us look at the reaction of Italian workers to the reform.

\section{The popularity of the TFR reform}

As illustrated above, Italian private sector wage earners had the first 6 months of 2007 to decide whether to divert their TFR flow to contractual or open PFs, or to leave them with the firm they worked for. If they did not explicitly express their will, the TFR flow was automatically diverted to a contractual PF, or to a special fund managed by INPS if the former did not exist in a specific industry. Table 2 (on p. 8I) shows that the number of private employees (those affected by the TFR reform) affiliated with PFs increased from 2.I6 million at the end of 2006 to 3.7 million by September 20I0, a 75.4\% rise. Most of the new members (78I thousand out of I,630 thousand) opted for the contractual funds, while the remaining wage earners decided for the open funds or other forms of private pension scheme. It can be seen that most of the increase occurred in 2007 , the year in which the reform was implemented. The total number of employees affiliated with PFs grew from 3.2 million in 2006 to 5.2 million in September 20I0, an increase of 64.I\%. As an effect of the crisis, the number of affiliated to the contractual funds fell both in 2009 and 2010.

According to official sources, almost I0o\% of workers explicitly expressed their choice: only 60 thousand workers adhered to the reform by the default clause (COVIP 2008: I6).

The success of the reform must of course be evaluated by considering the pool of workers potentially affiliated with a PF, that is the reform reference pool. In its assessments of the reform, the supervising authority (ibid: 20) took as the natural reference pool the number of workers, around 7 million, belonging to sectors in which well established contractual, industry-based PFs were operative, since a contractual fund is the most natural choice for an employee. After the reform, about $26 \%$ of the workforce proved to be affiliated with

return over the period I/I/I999-3I/IO/2008 (2.02\% per year) compared to a I0.4\% (I.04\% per year) return of the TFR left with the firms (Il Sole-24Ore, 29/11/2008). However, if we exclude the employer's contribution from the returns, and include it in the capital invested by the worker, then the total return is only $6.8 \%$ (o.7 per year), which is lower than the TFR return. 
contractual PFs (compared to about $17 \%$ in 2006). Adding another group of pre-reform PFs with a clear industry reference pool brought the participation rate to $32 \%$ (ibid: $2 \mathrm{I}$ ). Adding those affiliated with open PFs brought participation close to the final target of $40 \%$ set by the centre-left government.

Boeri and Zingales (2007) criticised the way COVIP artificially shrunk the reference pool, arguing that the genuine reference pool was the total number of employees in the private sector (I3.8 million). Apparently the supervising authority acknowledged the criticism and now estimates an affiliation share of $26.9 \%$ (to all sorts of PFs) (COVIP 20IOa: 44), well below the $40 \%$ target, itself a conservative goal. As mentioned above, a marginal minority, $4 \%$, of the over 3.5 million public employees and only $21.7 \%$ of the 6 million self-employed are affiliated with PFs. Self-employed were not involved in the TFR reform, but the government expected some indirect effect on their voluntary membership after the strong campaign conducted to convince employees in the private sector. All in all, $22.7 \%$ of the total employed population (about 23 million workers) is enrolled in a PF (notably, the fall of employment in 2009 determined a raise of this share by over one percentage point compared to 2008). The average yearly contribution to contractual or open PFs by wage earners was slightly above $€ 2000$ each in 2008 (COVIP 2009a: 69, 96). Self-employed affiliates, typically with open PFs, contributed about $€ \mathrm{I} 600$. Notably, in this class of workers $48 \%$ of those enrolled did not contribute at all in 2008; silent participation of employees is more limited, but it exists: $12 \%$ of those enrolled in open PFs did not make payments in 2008. These figures have increased in 2009 when, as a likely effect of the crisis, over 700 thousand enrolled (out of 5 millions) did not contributed at all. Most of them (40\%) are affiliated to the open funds, but many also to the contractual funds (I8\%) (COVIP 20I0a: 22, 43).

The data available shows very different rates of affiliation according to the size of firms. In large firms the rate of affiliation is close to $50 \%$ (mostly to contractual funds), whereas in sectors characterised by smaller firms the rate is limited to single digit figures. Disappointingly, younger workers - those who are supposed to be most interested in building their second pillar - show the lowest affiliation rate, though since the reform the distribution by age of those affiliated has shown increasing participation by younger generations. Sample data presented by Boeri and Zingales (2008) confirms a number of generally acknowledged factors that may have impeded greater participation in the TFR reform: workers in small firms may have little confidence in PFs and trust their employer more; the latter, in turn, may have persuaded them to retain the TFR within the firm; contractual funds may have been absent in industries characterised by small firms and workers were not confident about diverting their TFR to the special fund at INPS (on the other hand, in large firms, compulsory diversion of TFR not allocated to PFs to a little trusted special fund at the Treasury is said to have encouraged workers to allot it to PFs); unionisation is typically low in small firms and so is the level of information; in many small-firm sectors, employees did not benefit from the additional contribution by the employer if they devolved their TFR flow to a contractual fund. In contrast, in large unionised firms the higher percentage of new affiliations can be explained by the presence of well-established and advertised contractual funds. 
Last but not least, many workers in both small and large firms just did not like the idea of leaving the management of a beloved and well functioning institution, the TFR, to a financial sector perceived as unreliable even before the present crises. This has been attributed by mainstream economists to financial disinformation. Indeed, in spite of the fact that almost IOO\% of wage earners made a deliberate choice to adhere or otherwise to the reform - an indication of the profound concern of workers about the reform - most conventional commentators have indicated the lack of information and employees' 'financial illiteracy<, especially in sectors characterised by SMEs, as major factors that could explain the low rate of participation in the reform. This verdict should be evaluated in the light of a comment by the mainstream economist Roberto Perotti (Il Sole 24 Ore, 30/II/2008), admitting the ignorance of macroeconomists regarding the financial crisis that exploded in autumn 2008:

»Economists have been caught unprepared, mainly because knowledge about quite technical but fundamental details did not filter down from financial experts to macroeconomists in time« (my translation).

If this information failed to reach or be understood by the most credentialed minds in the economics profession, how could an ordinary worker be expected to process it? ${ }^{22}$ In the light of the present financial crises, we believe that most Italian employees who deliberately refused to take part in the reform had good reason to be suspicious.

\section{An assessment and a simple proposal}

From the point of view of increasing the number of wage earners affiliated with the FF pillar, the TFR reform has been a bland success. Only one fourth of Italian private sector employees took part in PFs in 2010 against one fifth in 2006, and almost none in the public sector. The financial performance of the funds has not been impressive, to put it mildly. Debate is open as to whether the financial crises that followed deregulation of national and international financial markets are the exception or the rule, and whether the development of PFs is itself part of the possibly increasing instability. It is, of course, difficult to take sides in this kind of debate, though the Keynesian-Kaleckian tradition would lean towards the structural instability of capitalism.

In judging the TFR reform, two arguments presented above should be kept in mind:

(a) the TFR reform is based on a change in management of an existing saving plan; any improvement in financial performance is therefore marginal and based on the supposition that returns from the financial markets will be higher than the TFR rate of return. Presumably, this will not be enough to radically improve the future retirement income of workers. ${ }^{23}$

22 For a thoughtful discussion of the pervasiveness of imperfect information in an inherently uncertain terrain such as social security, see Barr and Diamond (2006: 2O-2I).

23 For instance, estimations provided by Brugiavini (2007) suggest that if the rate of return from PFs is $2.8 \%$ (well above of the average shown in Table $\mathrm{I}$ ) and half the accumulated savings of an ordinary 
(b) the TFR reform is costly for the State and, at the end of the day, it might be the public purse that pays for the possible presumed higher return that workers may get from the change in management of their TFR funds. Being an unrepentant 'neo-Ricardian', I do apologise for $>$ Ricardian vicer way of reasoning. As mentioned in section 2, the TFR reform may be thought of as a shell gamer in which the TFR flow is diverted from firms to PFs, which in turn lend them back to the firms. Since firms now obtain the TFR funds at a higher cost, the State covers the difference. The alleged higher returns on TFR funds, financed in theory and in practice by the State, are shared between workers and the financial sector. Workers, however, finance the costs of the State through the tax system and possible cuts in social spending.

One might wonder whether it would not have been more convenient for the State to give this money directly to workers, e.g. in the form of tax relief on the existing accumulated TFR. My personal opinion is indeed that the TFR should not have been touched, except for three improvements: (i) extending inflation coverage to Ioo\% instead of the present $75 \%$; (ii) extending the tax concessions presently granted to PFs to the TFR and limiting them in the case of medium-high income savers; (iii) giving workers the possibility of transforming part or all of their accumulated TFR capital into an annuity at a convenient cost.

\section{Conclusions}

In Italy and other industrialised countries the need to develop the FF component arose from progressive cuts in the public pillar. For the general reader, not particularly interested in the intricacies of Italian pension reforms, the tale of the TFR reform is an example of the macroeconomic difficulties surrounding inception of a FF scheme, from scratch or by transition from a PAYG scheme, problems partially pointed out by the literature and expanded by the present author from a non-orthodox perspective. The main contention is that a FF scheme cannot be created by the stroke of a pen, since it encounters formidable obstacles: workers' saving decisions cannot be managed through legislative reforms, and even if the workers' saving supply increases, there is no analytical or empirical reason why capital accumulation should grow. Various ways of bypassing these difficulties have been proposed by 'pension experts and politicians. The Italian way out of the conundrum has been to use an existing company-based savings plan to set up a new one. Even admitting that workers might expect a higher rate of return on their TFR savings once they have been diverted to PFs, this supposed advantage must match the fiscal costs borne by the State costs that are at least partially passed on to the workers themselves. In any case, ten-year experience suggests that on average PFs have not financially outperformed the old TFR, and have shown highly variable returns. The TFR reform has mainly affected workers employed

employee with 38 years of contributions are transformed into an annuity (calculated at a rate of $2 \%$ ), this would be of $€ 3317$. By contrast, half the accumulated TFR, which is supposed to yield a rate of $2.4 \%$, would produce an annuity of $€ 2796$. The difference between the last two cases is not striking. 
by medium-large companies. Employees of SMEs have generally deliberately decided to leave the TFR with the firm, perhaps persuaded by their employers, or because they did not have direct access to large contractual PFs - the sort that workers naturally tend to trust most. Four years after the reform, a quarter of all wage earners and one fifth of the total labour force is affiliated with a PF, with no or only sporadic contributions in a number of cases. Workers have often been blamed for improvidence with regard to their old age, and accused of financial ignorance. On the contrary, most Italian employees made an explicit and difficult choice about their old age income, while dealing with the most deceptive capitalist market: the financial market. Considering the poor macroeconomic content of the TFR reform and the dubious advantages for workers of the change in management of their TFR savings, we conclude that the significance of the reform has been merely political, to show that governments and trade unions were doing something to offset the expected fall in PAYG pensions after the NDC reforms of the I990s, a political and economic shell game. Not surprisingly, most Italian employees were puzzled and unconvinced by the reform.

\section{References}

Agulnik, P., Le Grand, J. (1998): Tax relief and partnership pensions, in: Fiscal Studies, I9, $403-428$.

Arber, S., Ginn, J. (2004): Ageing and Gender: Diversity and Change, Centre for Research on Ageing and Gender, University of Surrey (UK).

Barr, N. (2006): Pensions: Overview of the issues, in: Oxford Review of Economic Policy, 22 (Spring), I-I4.

Barr, N., Diamond, P. (2006): Economics of pensions, in: Oxford Review of Economic Policy, 22 (Spring), $15-39$.

Boeri, T. (2008): TFR come tardiva e fallimentare riforma, FT Meeting Global Events, Milano, April.

Boeri, T., Zingales, L. (2007): Indipendenti sono le autorità o i numeri?, URL: http://www.lavoce. info.

Boeri, T., Zingales, L. (2008): Chi ha paura dei fondi pensione?, Milano: Anima Finlab, URL: http://www.fondianima.it.

Brugiavini, A., (2007): Tfr o fondi pensione, una scelta di convenienza, URL: http://www.lavoce. info.

Castellino, O., Fornero, E. (1997): Privatizzare la previdenza sociale?, Condizioni, modalità e limiti, in: Politica economica, $13,3-25$.

Ceprini, M., Modigliani, F. (1998): Social Security: una proposta per l'Italia, in: Economia Italiana, 2, 275-305.

Cesaratto, S. (2005): Pension Reform and Economic Theory: A Non-Orthodox Analysis, Cheltenham: Edward Elgar.

Cesaratto, S. (2006a): The transition to fully funded pension schemes: A non-orthodox criticism, in: Cambridge Journal of Economics, 30, 33-48. 
Cesaratto, S. (2006b): The saving-investment nexus in the debate on pension reforms, in: N. Salvadori (ed.), Economic Growth and Distribution. On the Nature and Causes of the Wealth of Nations, Cheltenham: Edward Elgar.

Cesaratto, S. (2007): Are PAYG and FF pension schemes equivalent systems? Macroeconomic considerations in the light of alternative economic theories, in: Review of Political Economy, 19, 449-473.

Cesari, R., Grande, G, Panetta, F. (2007): La previdenza complementare in Italia: caratteristiche, sviluppo e opportunità per i lavoratori, CeRP Working Paper, No. 60/o7.

Chiorazzo, V., Milani, C. (2007): Imprese ben compensate, URL: http://www.lavoce.info.

COVIP (Commissione di vigilanza sui fondi pensione) (2008): Relazione per l'anno 2007, Rome, URL: http://www.covip.it.

COVIP (Commissione di vigilanza sui fondi pensione) (2009a): Relazione per l'anno 2008, Rome, URL: http://www.covip.it.

COVIP (Commissione di vigilanza sui fondi pensione) (2009b), Hearing to the Chamber of Deputies of the Republic, Rome, January, URL: http://www.covip.it.

COVIP (Commissione di vigilanza sui fondi pensione) (20IOa): Relazione per l'anno 2009, Rome, URL: http://www.covip.it.

COVIP (20Iob): Main Statistics, Rome, October, URL: http://www.covip.it.

de Finetti, B. (1956): Sicurezza sociale e obiettivi sociali, in: de Finetti, B. (1965), Un matematico e l'economia, Milano: Franco Angeli.

Franco, D., Sartor, N. (2006), NDC in Italy: Unsatisfactory present, uncertain future, in: Holzmann, R., Palmer, E.E. (eds), Pension Reforms: Issues and prospects for Non-Financial Defined Contribution (NDC) Schemes, Washington, DC: The World Bank.

Garegnani, P. (1983): Notes on consumption, investment and effective demand, in: Eatwell, J., Milgate, M. (eds.), Keynes's Economics and the Theory of Value and Distribution, London: Duckworth.

Gronchi, S., Nisticò, S. (2006): Implementing the NDC theoretical model: A comparison of Italy and Sweden, in: Holzmann, R., Palmer, E.E. (eds), Pension Reforms: Issues and prospects for Non-Financial Defined Contribution (NDC) Schemes, Washington, DC: The World Bank.

Harcourt, G.C. (1972): Some Cambridge Controversies in the Theory of Capital, Cambridge: Cambridge University Press.

Holzmann, R. (1998): Financing the transition to Multipillar, World Bank Social Protection Discussion Paper, No. 992I.

Keynes, J.M. (1936): The General Theory of Employment, Interest, and Money, London: Macmillan.

Kotlikoff, L.J. (1999): The World Bank's Approach and the Right Approach to Pension Reform, URL: http://econ.bu.edu/kotlikoff/adb.pdf.

Messori, M. (2007): I problemi aperti nella previdenza complementare italiana, in: Quaderni europei sul nuovo welfare, 7, URL: http://www.newwelfare.org.

Robinson, J. (1953/4): The production function and the Theory of Capital, in: Review of Economic Studies, 2I, 8I-IO6. 
RGS (Ragioneria Generale dello Stato) (2008): Le tendenze di medio-lungo periodo del sistema pensionistico e sanitario: Rapporto n. Io, Rome, URL: http://www.rgs.mef.gov.it/ VERSIONE-I/Attivit--i/Spesa-soci/Attivit--d/2009.

Sraffa, P. (1960): Production of Commodities by Means of Commodities. Prelude to a Critique of Economic Theory, Cambridge: Cambridge University Press.

World Bank (200I): Notional Accounts-Notional Defined Contribution Plans as a Pension Reform Strategy, Washington DC. 
